\title{
The Knowledge Innovation Matrix (KIM): A Clarifying Lens for Innovation
}

\section{Shirley Gregor \\ School of Accounting and Business Information Systems \\ College of Business and Economics \\ The Australian National University Canberra, ACT, Australia}

\author{
Alan R. Hevner \\ Information Systems and \\ Decision Sciences \\ College of Business \\ University of South Florida \\ Tampa, FL, USA
}

ahevner@usf.edu

\begin{abstract}
Innovation is often understood in terms such as radical versus incremental, or exploratory versus exploitative, yet these terms are used loosely with little precision as to the type or amount of 'newness' found in the innovation. We suggest that innovations be judged on the basis of original knowledge contribution and needs addressed. Based on this fundamental definition, we propose a formal typology for categorizing innovations and the levels of both new knowledge contribution and real-world impact. The Knowledge Innovation Matrix (KIM) results from a classification of innovations and knowledge contributions on the two dimensions of application knowledge maturity and domain maturity. KIM provides a clarifying lens through which stakeholders can strategically manage innovation in multiple contexts. The matrix has four distinct quadrants termed (1) Invention, (2) Improvement, (3) Exaptation, and (4) Exploitation. We position this research in relation to existing innovation perspectives and briefly analyze the value propositions for innovations found in each of the quadrants in relation to the goals of the various innovation stakeholders in academia, industry, and government. Our aim is to produce a practical guide for developing a common understanding and a common language among academic researchers aiming at advancing knowledge, industrial managers aiming at new product and services, and government officials aiming at increasing the public welfare.
\end{abstract}

Keywords: Innovation, design science research, knowledge, innovation stakeholders.

\section{Quo Vadis, Innovation?}

Innovation drives economic growth and improves living conditions throughout the world. This

Material published as part of this publication, either on-line or in print, is copyrighted by the Informing Science Institute. Permission to make digital or paper copy of part or all of these works for personal or classroom use is granted without fee provided that the copies are not made or distributed for profit or commercial advantage AND that copies 1) bear this notice in full and 2) give the full citation on the first page. It is permissible to abstract these works so long as credit is given. To copy in all other cases or to republish or to post on a server or to redistribute to lists requires specific permission and payment of a fee. Contact Publisher@InformingScience.org to request redistribution permission. statement has been debated, analysed, and largely accepted since it was originally proposed by Joseph Schumpeter in his classic 1942 text, Capitalism, Socialism, and Democracy. Recent economic upheavals in the form of a worldwide recession have led to a deepening concern that innovation has become stagnant (Cowen 2011). While the debate rages on the current state of the innovation economy, a bright spotlight is being 
thrown on the topic of innovation. Difficult questions are being asked:

- What does innovation mean and how does it relate to terms such as invention, novelty, creativity, knowledge, and impact?

- How do human cognitive abilities in creativity and collaboration enable innovation? Can these abilities be developed through training to enhance innovation outputs?

- How do we define effective innovation processes and what are the innovative artifacts produced?

- How do we measure innovation success and how do we learn from innovation successes/failures?

- Who are the innovation stakeholders and how are their interests reflected in innovation processes and goals?

We see tremendous worldwide interest throughout industry, government, and academia to understand the answers to these questions and to get the innovation economy up to full speed. However, we believe progress is being stymied by the lack of a clear understanding of what we believe to be the essence of innovation - a contribution to human knowledge that addresses some need. In other words, a true innovation must advance human knowledge in a form that improves the human condition. Our goal in this paper is to propose a unifying innovation framework, the Knowledge Innovation Matrix (KIM), which provides a new clarity to innovation research, practice, and management. This lens will allow innovation stakeholders to better understand, manage, and improve innovation processes to achieve industrial, governmental, and academic goals.

Our work on the Knowledge Innovation Matrix began because of the authors' interests in facilitating methods in academia that would encourage more systematic and rigorous work in applied fields, such as Information Technology (Gregor \& Hevner, 2013). We also have clear interests in promoting innovation in industry as evidenced by our work on projects such as those found in Berndt, Hevner, and Studnicki (2003) and Gregor, Imran, and Turner (2013). However, it became obvious to us that in shifting across disciplinary boundaries we encountered areas in which understandings of innovation and applied research were quite different, having dissimilar and sometimes incompatible meanings and measurements of success. We had previously developed a framework to assist researchers in positioning knowledge contributions so that the significance and novelty of the contribution could be better recognized via academic publication (Gregor \& Hevner 2013). Our insight was that this framework could be modified and extended so that it could provide a guide to understanding the impact of knowledge contributions and real-world outcomes in innovation for a broader audience.

\section{Unifying the Innovation Landscape}

The territory covered by the term innovation is immense. The human actors in this landscape are many and varied, including managers, inventors, creative employees, entrepreneurs, university researchers, and policy makers. With such large coverage it is not surprising that it is hard to rise above one's immediate surroundings and take a global view of the innovation landscape.

All players concede that innovation is of vital importance to organizations, economies, and to society as a whole. "Virtually all of the economic growth that has occurred since the eighteenth century is ultimately attributable to innovation" (Baumol, 2002). Today innovative activities are strongly linked to business performance in innovation leaders such as Apple, Google, and Adidas (Innovaro, 2008). Innovations in areas such as medicine and medical devices have direct societal benefits for improving health outcomes. Research policy makers recognize the impacts that applied research and associated innovations can have on real-world outcomes (ATN, 2012). 
Although the ideas and goals of innovation have been widely studied in many different fields and contexts, there is a clear need for further work in developing a common framework for categorizing innovation so that communication and understanding amongst increasingly disparate stakeholders can be encouraged and enabled. In a world of distributed knowledge, "open innovation" means organizations do not rely entirely on their own research and development, but rather via innovation transfer between the organization and its environment (Chesbrough, 2003;

Chesbrough \& Appleyard, 2007; Clausen, Korneliussen, \& Madsen, 2013). As an illustration, approximately two-thirds of leading innovations in recent years are estimated to have come from collaborative partnerships involving business and government, including government funded labs and university research (Block \& Keller, 2008). However, much of the literature on innovation is organization-centric, coming from the perspective of innovation management within organizations (e.g., see Tidd \& Bessant, 2009).

We see many different perspectives when viewing innovation and innovation success. Industry leaders expect innovation success to result in greater market share and higher levels of profitability for resulting products and services. Governmental research funding bodies expect that external societal impacts from publicly funded research should be assessed, as in the United Kingdom's Research Excellence Framework (http://www.ref.ac.uk/) and the United States' National Science Foundation's Merit Review Criteria (http://www.nsf.gov/bfa/dias/policy/merit_review/). Academic researchers are interested in innovative activity as it leads to new knowledge contributions in traditional outlets such as archival journals. The theory bases that inform the study of innovation are as diverse as the players. In sum, the current innovation landscape has many disparate players with different goals and different understandings and measures of innovation.

\section{The Knowledge Innovation Matrix (KIM)}

It is important for the various fields involved with innovation to develop a more systemic, holistic view of innovation that promotes a broad understanding of different categories of innovations, related theories, and their outcomes, thus enabling in the longer-term more effective innovation practices and management to be shared among all stakeholders. To satisfy this need we propose a new sense-making lens to view and understand the broad innovation landscape and to allow players a more holistic view of the wider context, in order to communicate with other players and manage innovation more effectively. This device is KIM - the Knowledge Innovation Matrix.

We proceed by introducing the Knowledge Innovation Matrix (KIM) with concise explanations of the four quadrants. Illustrative examples of the contexts and theories that relate to the different quadrants are then provided, and we explore the use of KIM as an integrative lens for strategic innovation management in industry, government, and academia by proposing distinct value propositions. The paper concludes with a discussion of the implications of the study and future research directions.

Although we believe KIM is applicable to a broad range of innovations, both products and processes, this paper focuses on innovations that are IT-enabled. Such innovations, as explained in the theory section, arise from general-purpose technologies (e.g., the computer and the Internet), which have distinctive characteristics (Lipsey, Carlaw, \& Bekar, 2005), particularly their transformative or disruptive nature (Bresnahan \& Trajtenberg, 1995).

KIM relies on two key dimensions - application (i.e., opportunity, need, problem) domain maturity and knowledge (i.e. solution, artifact, theory) maturity. The matrix that results has four quadrants: (1) Invention, (2) Improvement, (3) Exaptation, and (4) Exploitation. The resulting typology is theoretically significant as it is firmly based in theory of the economics of knowledge and innovation (Mokyr, 2002). No similar unifying classification schemes in the extant literature can be found. The typology does, however, extend and combine prior work on classifying knowledge 
contributions (Gregor \& Hevner, 2013) and organizational strategy classifications (e.g., Ansoff, 1957; Danneels, 2002). The typology has practical managerial importance. It provides an integrative view for research policy makers and academic researchers. For strategic management in organizations it provides an update on tools that have had a tremendous impact already, for instance the Ansoff matrix (Ansoff, 1957). Appendix A provides an extended comparison of KIM with these previous management tools.

KIM is built firmly on the most fundamental feature of innovation - new knowledge applied in some tangible form to achieve human goals. The tangible forms that innovations take include products, processes, and services. Taking knowledge and its application as the keys to understanding innovation means that many other labels and categorizations that only partly deal with the innovation space are encompassed: ideas, creativity, technological know-how, products, competencies, organizational learning, and exploration versus exploitation. That knowledge is the key feature in all of these terms is apparent on reflection. Companies do not value the innovative products they produce so much in themselves as the knowledge assets they embody. After all, they sell these products to consumers. What they value is the knowledge asset represented in the product - the intellectual property that may be worth protecting by patents, trade secrets, and/or copyrights.

A fundamental issue when considering innovation is that rarely is knowledge really 'new.' Everything is made out of something else or builds on some previous idea. When is something really novel or a significant advance on prior work? An innovation project has the potential to make different types and levels of knowledge contributions depending on its starting points in terms of problem maturity and solution maturity. This variation reflects a project's placement along the timeline of knowledge growth in the discipline and is related to the problem maturity and solution maturity available and relevant to the project.

The choice of these two dimensions as the primary means of classifying innovations depends on important existing theories of innovation.

- The knowledge (solution) maturity dimension resonates with the key roles in innovation of new ideas (Rogers, 2003; Van de Ven, Polley, Garud, \& Venkataraman, 2008), new insights (Mascitelli, 2000), new knowledge and skills (Leonard-Barton, 1992), technological know-how (Rothwell \& Gardiner, 1985), new knowledge (Levinthal \& March, 1993), and learning (March, 1991).

- The application domain (problem) maturity dimension resonates with the key roles in innovation of opportunities (Tidd \& Bessant, 2009), tasks and problems (Horenstein, 2002), markets (Danneels, 2004), needs (von Hippel \& von Krogh, 2013) and fields (Cropley \& Cropley, 2010).

Tidd and Bessant (2009, pp. 229-232) explicitly recognize the salience of these two key dimensions in their description of the two main sources of innovation: "knowledge push" and "need pull". Appendix B provides a more detailed analysis of the relationships between the chosen dimensions and related theoretical concepts.

The outcomes of innovation are also of interest to this proposed strategic lens. Outcomes will vary with both the knowledge and the application dimension in combination and include both (i) knowledge contributions that are measured in part by scholarly metrics (e.g., publication outlet, citations, patents) and (ii) real-world impact with measures that are of interest to stakeholders in industry (e.g., new markets, increased profits, competitive advantage) and society (e.g., cultural inclusion, societal benefit, national productivity). Emphasis on the importance of these outcomes varies between industry, government, and academia stakeholders. A view on how both research outcomes and impact can be measured from a research policy view is given in the "Payback 
Framework" developed in a health care context (Donovan \& Hannay, 2011). Some innovations are spoken of as transformative or disruptive technologies. These terms refer to the outcomes of innovation and the degree of impact that is achieved - something that can be assessed only in hindsight.

Thus, Figure 1 presents a $2 \times 2$ matrix of innovation contexts and potential knowledge contributions and impact. The $\mathrm{x}$-axis shows the maturity of the knowledge that exists as potential starting points for solutions from low to high. The y-axis represents the current maturity of the application domain or the problem context again from low to high. Note that the boundaries between these categories are fuzzy rather than fixed and work on innovation projects is likely to flow from one quadrant to another over time, as discussed further in the section dealing with over-arching theories.

We proceed to explore the four quadrants, labeled (1) Invention, (2) Improvement, (3) Exaptation, and (4) Exploitation. In each quadrant, we briefly describe the contextual starting points of the innovation in terms of problem and solution knowledge foundations. For each quadrant, we also discuss the types of knowledge and impact contributions that can be made in terms of different types of artifacts and/or theories.

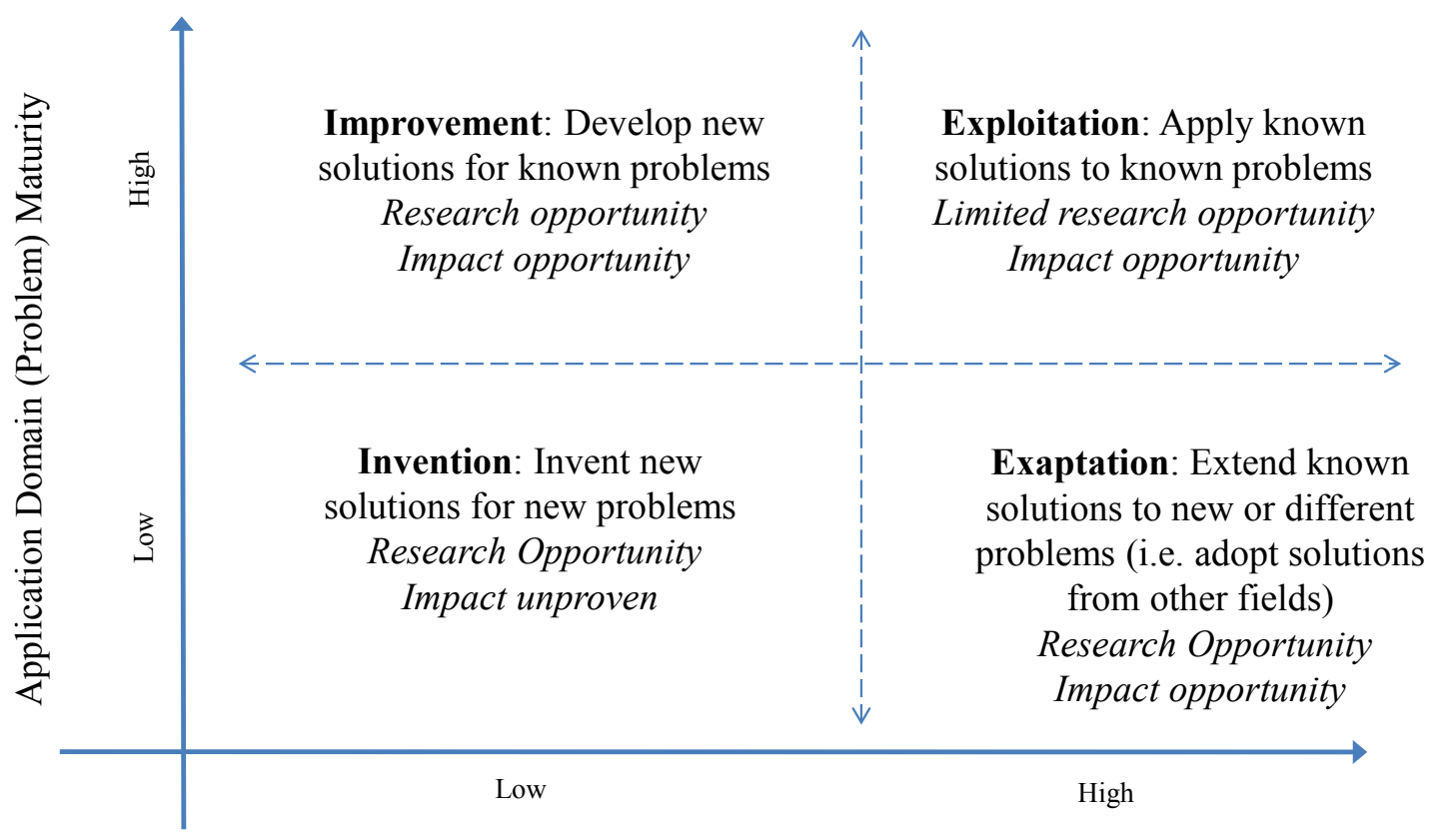

Knowledge (Solution) Maturity

Figure 1: Knowledge Innovation Matrix (KIM) with Opportunities for Research and External Impact Outcomes

\section{Invention - New Solutions for New Problems}

True invention is a radical breakthrough innovation - a clear departure from the accepted ways of thinking and doing. The invention process can be described as an exploratory search over a complex problem space that requires cognitive skills of curiosity, imagination, creativity, insight, and knowledge of multiple realms of inquiry to find a feasible solution. While this process of invention is perhaps ill-defined, invention activities can still be recognized and evaluated in a realworld context based on their resulting artifacts and knowledge contributions. 
Innovation projects in this quadrant will entail research in new and interesting applications where little current understanding of the problem context exists and where no effective artifacts are available as solutions. In fact, so little may be known about the problem that research questions may not even have been raised before. Knowledge contributions in this quadrant result in recognizably novel artifacts or inventions. In this category appear artifacts where the idea of the artifact itself is new, for example, the first bicycle or the first decision support system. This type of work does not fit neatly with some models of innovation where the first step is described as "define the research problem and justify the value of a solution" (see Peffers, Tuunanen, Rothenberger, \& Chatterjee, 2008). In this quadrant, a recognized problem may not necessarily exist and the value of a solution may be unclear. As Simon (1996) says, the researcher may be guided by nothing more than "interestingness." In part, a key contribution is the conceptualization of the problem or opportunity itself.

Examples of invention are rare but highly visible, such as camera/photography (1816-36), phonograph (1877), pyrex (1912), computer mouse (1963), planning robot (1966), object oriented programming (1967), and micro fuel cells (2003). Additional examples of information technology (IT) inventions would include the first thinking on Decision Support Systems (DSS) by ScottMorton (1967), with the subsequent evolution of DSS into Executive Support Systems (ESS) (Rockart \& DeLong, 1988) and Group Decision Support Systems (GDSS) (Nunamaker, Dennis, Valacich, Vogel, \& George, 1991).

Knowledge flows in the invention quadrant are typically inductive, from instances to eventual generalization. The new artifact is invented and then other researchers see it employed in use and begin to formulate descriptive knowledge about its use in context (in a different quadrant). A persuasive example is the inventive work by Agrawal, Imielinski, and Swami, (1993) that began the field of data mining and data analytics. They developed what appears to be the first full conceptualization of mining databases for association rules as well as an efficient method for discovering them. As an 'invention' this paper has generated and influenced a whole new field of research.

Yet, most often the real-world impacts of innovations in this category are uncertain and unproven. History shows that many apparently good ideas have been spectacularly unsuccessful, for example, the Edsel Ford automobile and Motorola's world-wide mobile communication network of the 1990s (see Tidd \& Bessant, 2009).

\section{Improvement - New Solutions for Known Problems}

The goal of innovation in the improvement quadrant is to create better solutions in the form of more efficient and effective products, processes, services, technologies, or ideas. Innovators must contend with a known application context for which useful solution artifacts either do not exist or are clearly suboptimal. They will draw from a deep understanding of the problem environment to build innovative artifacts as solutions to important problems. The key challenge in this quadrant is to clearly demonstrate that the improved solution genuinely advances on previous knowledge.

Much of the previous and current innovation work belongs to this quadrant of improvement research. Examples would include improved digital cameras, better robots, and higher resolution display screens. An example in the field of strategic management is McLaren, Head, Yuan., and Chan's (2011) multi-level model for strategic fit, which addresses a need for "a more finely grained" (p. 2) tool for diagnosing strategic fit. A classic information systems example is the research stream of improvements to the GDSS literature as exemplified by Nunamaker, Dennis, Valacich, and Vogel (1991). This article studies how the design of improved anonymity features impacts the effectiveness of option generation in negotiating groups using GDSS.

Improvement innovation research is judged first on its ability to clearly represent and communicate the new artifact design. The presentation will show how and why the new solution differs 
from current solutions. The reasons for making the improvement should be grounded in appropriate theories from the domain knowledge base. Once the design improvement is described, then the artifact must be evaluated to provide convincing evidence of its improvement over current solutions. Improvement may be in the form of positive changes in efficiency, productivity, quality, competitiveness, market share, or other quality measures, depending on the goals of the project.

In the improvement quadrant, innovation projects make knowledge contributions in the form of artifacts and/or generalized theories. Situated instantiations are often constructed to evaluate the level of improvements in comparison with instantiations of the existing solution artifacts. As appropriate, more general artifacts in the form of constructs, methods, models, and design principles are proposed as generalized knowledge improvements. Further, the evaluations of the improved artifact may lead to knowledge contributions in the form of expanded understanding of existing theories or the development of new theories of the artifact in use.

The impact of innovations in business in the form of improvements can be considerable. The Canadian Intellectual Property Office reports that $90 \%$ of new patents are improvements upon existing patents. Many of Edison's wealth-producing innovations were improvements on existing ideas. For example, more than 100 patents were given for the electric light bulb alone (see Cropley \& Cropley, 2010).

\section{Exaptation - Known Solutions Extended to New Problems}

Original ideas often occur to individuals who have experience in multiple disciplines of thought. Such training allows interconnections and insights among the fields to result in the expropriation of ideas and artifacts in one field to solve problems in a different field. Thus, we may face an innovation opportunity in which artifacts required in a field are not available or are suboptimal. However, effective artifacts may exist in related problem areas that may be adapted or, more accurately, exapted to the new problem context (Gould \& Vrba, 1982). In this quadrant are contributions where design knowledge that already exists in one field is extended or refined so that it is extendable to some new application area.

This type of innovation project is common where new technology advances often require new applications (i.e., to respond to new problems) and a consequent need to test or refine prior ideas. Often, these new advances open opportunities for the exaptation of theories and artifacts to new fields. Exaptation innovations would include robots used in military applications, medicine, and companionship, and digital cameras used in phones. Exemplars of exaptation in IT research include Berndt et al.'s (2003) research on the CATCH data warehouse for health care information where well-known methods of data warehouse development (e.g., Inmon, 1992) are exapted to new and interesting areas of health information systems and Chaturvedi, Dolk, and Drnevish's (2011) design principles for the user experience in virtual worlds where the user experience in this context could be expected to be significantly different from online experiences in general. Another recent example of exaptation is the design of an Embodied Conversational Agent (ECA) based kiosk for automated interviewing (Nunamaker, Derrick, Elkins, Burgoon, \& Patton, 2011). This project exapts existing sensors and intelligent agents to the innovative design of systems for use in automated deception detection.

In exaptation projects, the innovator needs to demonstrate that the extension of known design knowledge into a new field is non-trivial and interesting in order to claim a knowledge contribution. The new field must present some particular challenges that were not present in the field in which the techniques have already been applied else the use would be more aptly characterized as adoption. In the exaptation quadrant, knowledge contributions can be in the form of artifacts and generalized theories as appropriate to the project goals. Generalized knowledge contributions may 
also be produced via a greater understanding of the new artifacts in use. Exaptation innovations can have considerable real-world impact. The process here can also be described as the leveraging of existing knowledge to new applications, or "cross application", with significant innovations resulting (Banerjee, 2008).

\section{Exploitation - Known Solutions for Known Problems}

Exploitation occurs when existing knowledge for the problem area is well understood and when existing artifacts are used to address the opportunity or question. Opportunities for knowledge contributions in this quadrant are less obvious, and these situations rarely require research methods to solve the given problem. Such work is not normally thought of as innovation (i.e., contributing to new knowledge) because existing knowledge is applied in familiar problem areas in a routine way. However, routine work may in some cases lead to surprises and discoveries (see Stokes, 1997); but, in such cases, these discoveries will likely involve moving the innovation project to one of the other quadrants in terms of knowledge contribution.

It is important that high-quality professional design or commercial system building be clearly distinguished from knowledge innovation. Professional design is the application of existing knowledge to organizational problems, such as constructing a financial or marketing information system using "best practice" artifacts that exist in the knowledge base. Contributions to knowledge here may come from better understanding of strategic management of innovations within organizations and change management (e.g., Gregor et al., 2013).

This quadrant is the pure exploitation quadrant. Although projects in this quadrant may add little to formal knowledge of the innovation itself, it is possibly the quadrant in which the impacts of an innovation are maximized. The innovation may not be "new to the world", but an organization might see it as "new to us" and derive considerable value, possibly with only relatively minor adaption of the core knowledge innovation to allow it to apply to the organization. In terms of the well-known Gartner Hype Cycle, this is the "Plateau of Productivity" where mainstream adoption occurs and the real-world benefits of a new technology are demonstrated and accepted (Linden \& Fenn, 2003).

\section{Integrating Innovation Perspectives}

KIM provides an integrative view of the perspectives and theory bases related to innovation. Some theorists, either explicitly or implicitly, aim their theory at one category of innovation more than another. The use of KIM allows innovation researchers to see how their theory relates to the greater whole. In this section we provide some illustrative examples of how some theories can be applied in the context of KIM.

We begin by examining theory that has an encompassing view of innovation, often looking at the development of innovations over time. Then we examine theory that appears to apply to one quadrant more than the others. We use our judgement in making these distinctions as authors frequently do not explicitly define the boundaries of their work and the category of innovations they have in mind. We have used the terms in which they frame their theory to identify the category with which it best fits. Note we are providing illustrative examples of important theories and perspectives. It is beyond the scope of this research note to attempt anything like a comprehensive review of the innovation literature.

\section{Broad Innovation Perspectives}

A number of theories take a broad view of innovation, often considering how innovations develop over time. These theories are of interest to government stakeholders, amongst others, who need to 
take a broad view of innovation in managing the economy and in research policy. It is these broader theories that provide the underlying rationale for KIM.

The field of economics of knowledge is a rapidly growing sub-discipline of economics (Foray, 2004). Knowledge-intensive activities, such as innovation, are studied for their historical impacts on societies and cultures (Mokyr, 2002). Broad theories are proposed around the efficient growth of economies based on their production, management, and consumption of knowledge. Key topics include appropriate incentives for the efficient production of knowledge and the trade-offs of public access to knowledge (e.g., open sources) vs. privatized exploitation of knowledge (e.g., proprietary patents).

In this work, information technology is seen as a General Purpose Technology (GPT). GPT theory is rooted in evolutionary economics, dating back to Schumpeter (1934), and received heightened attention following the work by economic historian David (1990). Bresnahan and Trajtenberg (1995) were the first to describe IT as a revolutionary GPT, like electricity, that can lead to sustained innovation based growth. IT is seen as special "transformative" type of GPT that requires complementary organisational change to reap full benefits; change that can take some time. "As a GPT evolves and advances it spreads through the economy, bringing about and fostering generalized productivity gains" (Bresnahan \& Trajtenberg 1995, p. 84). There is now considerable empirical support for the GPT view and it is used in a wide range of economic applications (see Helpman, 1998), especially in finding an answer to the "productivity paradox" with respect to information technology (Solow, 1987). In terms of KIM, the GPT occurs first as an invention (e.g., the first computer), is refined in the improvement quadrant, and then is used for purposes other than originally anticipated in the exaptation quadrant. The full potential of the GPT, however, is only realized when it is incorporated into practice in industry via exploitation with corresponding organizational change. David (1990) noted a long delay between the introduction of a radical new technology and its impact on productivity.

At the organizational level the work of Nonaka and colleagues on the "knowledge-creating" company depict the central importance of knowledge for innovation and focus on changes from tacit to explicit knowledge in a spiral process (e.g., Nonaka, 1991; Nonaka, Toyama, \& Nagata 2008). Nonaka (1991) shows how innovations are linked to novel ideas, which can be gleaned from individual's tacit knowledge. For example, the Matsushita product development company incorporated ideas obtained from careful observation of an expert human bread maker into the design of a superior bread making machine (an improvement innovation).

Some practitioner-based perspectives also recognize the different attributes of innovations over time. A popular view is the Gartner Group's "hype cycle" (Linden \& Fenn, 2003), which is a graphic portrayal of the maturity, time to adoption, and business application of particular technologies. The hype cycle is initiated by a "technology trigger", a technological breakthrough (invention), followed by first-generation products that are specialized and expensive. At the "peak of inflated expectations" and in the "trough of disillusionment", the technology may be pushed to its limits and early trials may be failures. However, focused experimentation (improvement) and use by an increasingly diverse range of enterprises (exaptation), leads to climbing of the "slope of enlightenment". Finally, for some technologies, the "plateau of productivity" (exploitation) is reached. "Technologies become increasingly embedded into solutions that increasingly are "out of the box' with decreasing service elements as the technology matures" (Linden \& Fenn, 2003, p. 9).

An extremely influential characterization of distinctions among innovative activities is the exploration-exploitation view of organizational learning introduced by March (1991). March saw exploration as "search, variation, risk taking, experimentation, play, flexibility, discovery, innovation" (p. 71). Exploitation was "refinement, choice, production, efficiency, selection, implementa- 
tion, execution" (p. 71). He viewed exploration and exploitation as both vital activities within a firm. Returns from exploration would be less certain and occur over a longer timeframe compared with returns from exploitation. In KIM terms, exploitation is the fourth quadrant of innovation, while the other three quadrants are all aspects of exploration. KIM thus offers a finer-grained view of innovation categorization.

We now proceed to give brief examples of theorising that has focussed on specific phenomena in each of the four quadrants.

\section{Invention Quadrant}

Theories of creativity are used to explain what leads to true invention. To cite one prominent example, Amabile's (1983) componential theory of creativity posits that four components are necessary for a creative response: three components are interpersonal - domain-relevant skills, creativity-relevant processes, and intrinsic task motivation. One component is external to the individual - the social environment in which the individual is operating. Amabile (2012) states that the current version of the theory is applicable to organizational creativity and innovation. Consider the example of e-readers (the Sony eReader and Amazon Kindle) which she says are "notably different from anything that had come before" (p. 5) (thus, an invention). She shows how this example is consistent with her creativity theory. For instance, the environment at the MIT Media Lab is identified as highly favourable to creativity and invention: having a wide range of disciplines; psychological safety where people could present "wild" ideas; autonomy for researchers; and good facilities for experimentation.

\section{Improvement Quadrant}

The goal of "building a better mouse trap" has a profound call to humans who want to improve ways and means of work and everyday human experience. A well-known theory that applies to this quadrant is the knowledge-based theory of the firm as described in research by Grant (1996), Foss (1996), and Spender (1996). Knowledge as a significant resource of a firm must increase over time to provide sustained competitive advantage and improved corporate performance. Thus, innovation results in the continuous improvement of organizational products and processes required for the firm to maintain relevance in a changing market environment.

Such knowledge-based views of the firm have been extended to apply to information technologies and systems as primary drivers of organizational change (e.g.. Alavi \& Leidner, 2001). Likewise, theories underlying design science research approaches in information systems are highly relevant to this quadrant. Much of the work in this area has been couched in terms of "problem solving" - that is, the application area is relatively well known and the possibility of providing improved solutions is evident. In Simon's (1996) terms the problem is known and welldefined, or can be made well-defined, and improved solutions can be devised using fairly traditional techniques within the discipline.

\section{Exaptation Quadrant}

Theory in the exaptation quadrant draws in part on theories of creativity; for instance, Sternberg, Kaufman, and Pretz (2002) see one of the ways in which creativity occurs as being conceptual replication, where existing knowledge is transferred to a new field. However, there is also theorizing that is more directly applicable to this quadrant. Von Hippel and von Krogh (2013) describe "need-solution pairs" in which a need and a solution are discovered together. Although this description might sound like the invention quadrant, few if any of the examples given are true inventions, that is, new to the world. One example given (from von Hippel, 1986), is of a lead user search for mechanisms to be used for cars to avoid collisions. The search for a solution is 
widened to many solutions of similar problems - for example, how blind individuals successfully navigate crowded sidewalks.

Crowdsourcing provides further application of these ideas. Jeppesen and Lakhani (2010) study the outcomes of problem-solving challenges issued by the outsourcing firm Innocentive. Many of this firm's clients had more diverse expertise sets than the in-house research staff and thus are able to suggest solutions exapted from other fields.

\section{Exploitation Quadrant}

Considerable attention in the field of innovation management examines innovations falling into this quadrant - being "new to us", rather than "new to the world." Rogers' theory of the diffusion of innovations (Rogers, 2003) and the Technology Acceptance Model (TAM) (Davis, 1989) apply here. Some models of user appropriation of technology are also relevant, where the basic idea and purpose behind the innovation is not changed, but it is customized or modified by the user to some degree.

Dong, Karhade, Rai, and Xu (2013) provide a useful recent review of innovation in this quadrant. They explicitly define innovation (p. 2) as "The organizational change aiming to improve certain organizational outcomes." The focus is on the use of IT to achieve organizational goals - there is no mention of "invention." The theoretic themes identified in a comprehensive review of the information systems literature are resource-based theory, behavioural theory of the firm, evolutionary theory, property rights theory, agency theory, and transaction costs theory. There is little attention on creativity or design work, which we would expect to find if the other three quadrants were included.

\section{Applying KIM to Innovation Management - Value Propositions for Academia, Industry, and Government}

The use of KIM as an aid to better understand and manage the varieties of innovation supports a set of value propositions for further investigation and research. In this section we briefly state and discuss several propositions with impacts for various stakeholders in the fields of academia, industry, and government.

\section{Academic Value Propositions}

Innovation in academia concerns the rigorous consumption and production of knowledge (Gregor \& Hevner, 2013). A separate body of work examines research practice and academic knowledge contributions in dedicated research institutions such as universities. For subfields of IT, including information systems, computer science, and engineering, this work explores research practices, research approaches, and the philosophy of technology/science. It includes coverage of the sciences of the artificial (Simon, 1996), computer science methods (Zobel, 2005), software engineering research (Parnas, 2011), and design science research (DSR) (Gregor \& Jones, 2007; Hevner, March, Park, \& Ram, 2004). In particular, the DSR approach provides for scientific rigor in applied problem solving settings. The economics of scholarly knowledge production are also examined (e.g., Mokyr, 2002).

Outcomes of scholarly activity are typically examined in terms of quality of publication outlets, citations, and scholarly reputation indicators. This work uses a different language from the innovation studies and has relatively little discussion on how real-world impacts outside the development environment and academic circles can be achieved. This situation may be changing, however, with recognition by research funding and accreditation bodies, such as the Australian Research Council and the Association to Advance Collegiate Schools of Business (AACSB), that external 
impact is expected from publicly funded research and that it should be assessed (AACSB 2008; ATN 2012).

Academic Value Proposition 1: In the Invention quadrant:

(a) Research outcomes will be significant although instances may be rare.

(b) Rigorous measurements of knowledge contributions must be provided to provide convincing evidence of new thinking.

(c) Real-world impact is unproven and uncertain.

Academic Value Proposition 2: In both the Improvement and Exaptation quadrants:

(a) Research outcomes will occur relatively frequently.

(b) Rigorous measurements of knowledge contributions must be provided to provide convincing evidence of new thinking.

(c) Real-world impacts can be substantial.

Academic Value Proposition 3: In the Exploitation quadrant:

(a) Research outcomes will be negligible, both in terms of number of occurrences and significance.

(b) Research impacts will be found in the form of technology transfer articles in practitioner outlets.

\section{Industry Value Propositions}

There is a large body of work on innovation in industry, including innovation management (Tidd \& Bessant, 2009), incentives for innovation (Lerner, 2012), innovation models (Van de Ven et al., 2008), innovation practices including creativity facilitation (Savransky, 2000), and innovation outcome indicators (S. Brown \& Eisenhardt, 1995). However, attention to formal knowledge capture and flows in this stream of work is scant (although see Leonard, 1998). For instance, the book by Tidd and Bessant (2009) on managing innovation has a section on "exploiting knowledge and intellectual property" (pp. 541-564) but this section deals primarily with knowledge management within an organization, not contribution to wider knowledge.

Prior taxonomies such as the Ansoff matrix have been used successfully in industry for strategic management such as market diversification. However, KIM gives a more holistic view that will allow people engaged in collaborative industry-academic ventures to gauge the likely outcomes of projects and to plan a portfolio of projects. These plans can take into account existing evidence from innovation studies within organizations: for example, Auh and Mengue (2005) find that 'exploitation' (Exploitation quadrant) contributes to short-term growth (return on assets) while 'exploration' (other three quadrants) contributes to long-term performance (market-share growth, sales growth). Similarly, the Gartner Hype Cycle suggests the biggest impact payoffs come in the "plateau of productivity" (i.e., Exploitation).

Industry examples of innovation models and practices are illustrated by the application of IDEO methods of design consultancy (Kelly, 2002). While many industrial models of innovation are held closely as proprietary secrets, several companies have outlined their methods in practitioner publications, such as $\mathrm{P} \& \mathrm{G}$ 's four types of innovation (sustaining, commercial, transformational, and disruptive) (B. Brown \& Anthony, 2011) and Merck's technology innovation experimental process (Ray, 2008). 
Industry Value Proposition 1: In the Invention quadrant:

(a) Investments in new radical innovation are sometimes limited by requirements for shortterm returns on investment. Significant resources may be required with little certainty of results.

(b) It is difficult to measure organizational impacts in this quadrant.

Industry Value Proposition 2: In the Improvement quadrant:

(a) Resources are allocated to continually improve the products and processes (knowledge assets) of the organization.

(b) Evaluation of improvements is essential to provide evidence of knowledge contributions.

(c) Organizational impacts will be based on speed to market, increased market share, and new revenue generation.

Industry Value Proposition 3: In the Exaptation quadrant:

(a) Resources are allocated to explore emerging and important new market opportunities for the organization. Ignoring new markets and new technology platforms may lead to stagnation in the current market (e.g., the innovator's dilemma (Christensen, 1997)).

(b) Movement to new markets entails risks of new competitors, unknown knowledge bases, and ill-defined knowledge contributions.

(c) Organizational innovation in this quadrant may involve mergers and acquisitions with companies which have innovations in aligned new markets.

(d) Organizational impacts will be based on diversification goals, potential of new markets, and future visions.

Industry Value Proposition 4: In the Exploitation quadrant:

(a) Resources will be allocated to maintain market position and continue revenue streams.

(b) New knowledge contributions are negligible.

(c) Real-world impact based on best practices can be significant.

\section{Governmental Value Propositions}

The government (or public sector) perspective on innovation concerns the economic and societal welfare of the governed population. This is necessarily a 'big picture' view of the need for innovation to improve the human condition. Governmental actions, such as providing funding for academic research or industrial innovations (e.g., clean energy), have the goal of encouraging and enabling a dynamic innovation culture and economy (see Dolfsma \& Seo, 2013).

Government is recognized as one of the three major forces in the dynamics of innovation, along with industry and academia in the triple helix model (see Etzkowitz \& Leydesdorff, 2000). Government can stimulate processes in which basic research is linked to utilization of innovations when forces within academia and industry are insufficient by themselves to achieve this goal. Government bodies see themselves as heavily involved in the building of national innovation systems, with the aim of making their nation more productive and more competitive (e.g., see Commonwealth of Australia, 2009).

Government Value Proposition 1: In the Invention quadrant:

(a) Funding of pure research that may lead to inventions and new theories is an important role of government research agencies as a public good.

(b) Evaluation of future impacts of radical innovation is difficult.

(c) Rigorous measurements of knowledge contributions must be provided to provide convincing evidence of new thinking. 
Government Value Proposition 2: In the Improvement quadrant:

(a) Funding for improvement innovation must be judged on the potential for societal good that can result in the area of improvement.

(b) Evaluation of improvements is essential to provide evidence of knowledge contributions.

(c) Societal impacts will be based on indicators such as improved living conditions, improved access to government services, and increased economic opportunities.

Government Value Proposition 3: In the Exaptation quadrant:

(a) Funding for exaptation innovation must be judged on how critical new platforms and environments are for the provision of more transparent, secure, efficient, and equitable government services. For example, funding to support the movement of government services to cloud-based environments.

(b) Government innovation in this quadrant may involve contracting with companies which have innovations in emerging new markets.

(c) Societal impacts will be based on indicators such as improved living conditions, improved access to government services, and increased economic opportunities.

Government Value Proposition 4: In the Exploitation quadrant:

(a) Government spending for best practice IT systems and services must rely on clearly defined and equitable contracting policies. This will be outside of government research funding agencies.

(b) Real-world impact based on best practices can be significant.

\section{Discussion and Conclusions}

We propose that KIM provides a new and more useful lens for the strategic management of innovation across diverse stakeholders in academia, industry, and government. As compared with prior categorizations of innovations, it is more inclusive and better grounded in theory. It gives a basis for resolving prior inconsistencies in defining innovation as it recognizes four categories of innovation that are distinctive with different value propositions for the stakeholders. Our claim is that KIM will be useful to policy makers and researchers as well as managers of innovation in organizations. It will help people in collaborative innovation initiatives to better understand each other's point of view. KIM offers a means for researchers and industry to categorize innovations and understand the range of outcomes and value to be expected with each category.

\section{Innovation as an Informing Science}

The view of innovation as an informing science is appropriate when innovation is considered as a search process on a complex fitness landscape of possible solutions to the innovation opportunity. KIM with its foci on problem maturities and solution maturities to distinguish different categories of innovation clearly reflects the information needed by an agent in an informing science study (Gill \& Bhattacherjee, 2007). During an innovation project, the innovation team (or agent) must become informed on the dynamics of the innovation landscape and the search process employed to find the highest fitness peaks on the landscape. The exploitation quadrant would imply rather mature understandings of problem environment and the high-fitness solutions to the problem. At the other extreme, the invention quadrant would deal with immature landscapes which are highly dynamic. In other words, the search for innovative solutions will change the landscape as the search itself provides new understandings of both the problem and what determines an effective solution to the problem (Gill \& Hevner, 2013). The improvement and exaptation quadrants demonstrate intermediate levels of problem and solution maturities in the landscape in which the search process can be informed by known information to discover higher fitness innovations in the posed problem landscape. 


\section{KIM and Innovation Impacts}

KIM can be used to structure future studies of innovation impacts. Figure 2 provides additional insights on how the KIM innovation categories support an improved understanding of the innovation economy. This conceptual model is developed from prior literature and from our initial work on the typology for innovation categories. The model builds on the extensive studies on innovation in organizations (S. Brown \& Eisenhardt, 1995), and the themes of Van de Ven and Poole (1990), with the addition of constructs to recognize that in collaborative initiatives knowledge production is an important outcome in addition to innovation impact. The model explicitly includes the KIM "innovation categories" as an overarching influence on relationships as the nature of research and innovation practices is seen to depend on the type of innovation.

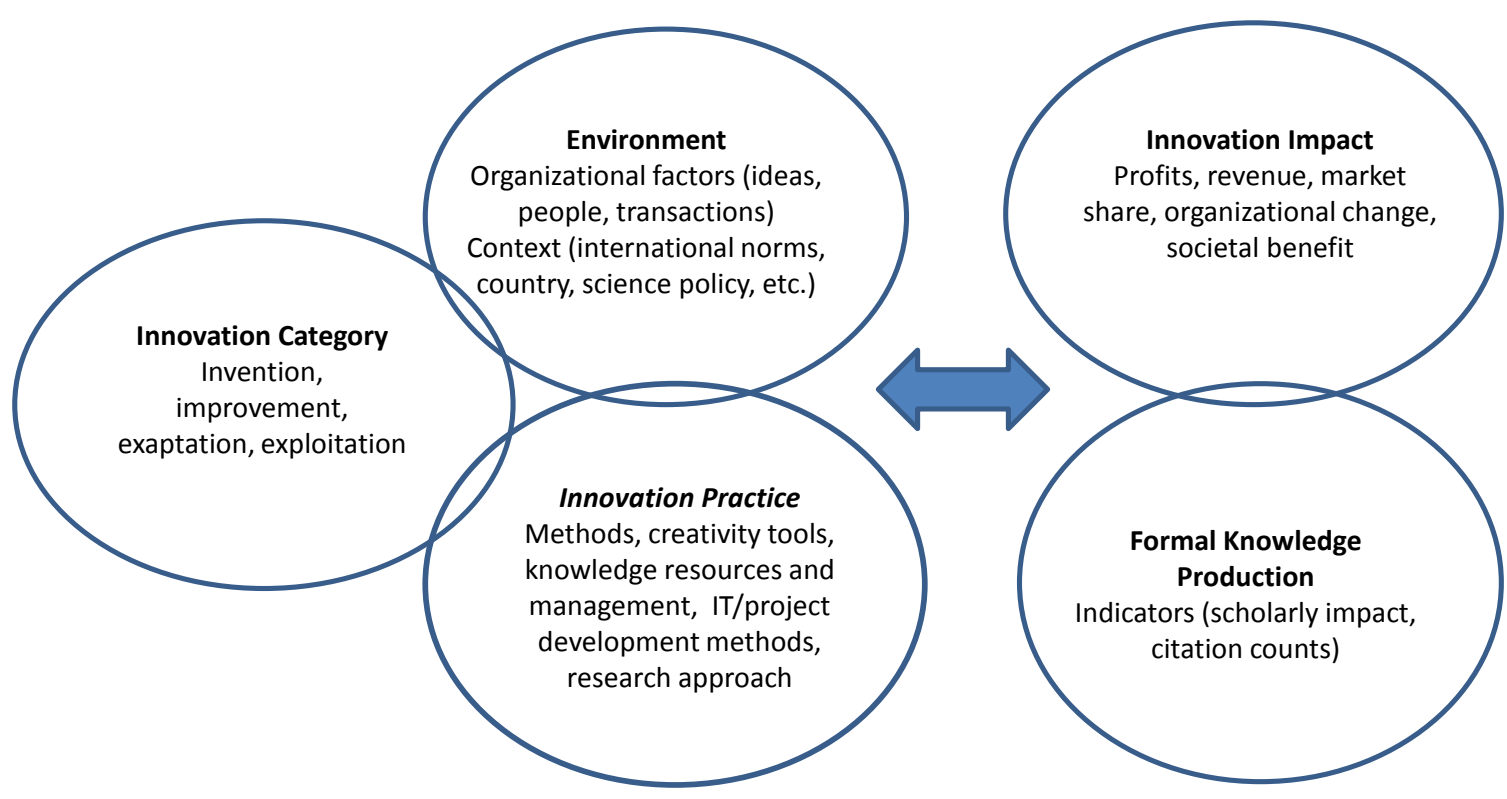

Figure 2: A Conceptual Model of Innovation Research and Practice

\section{Future Research Directions}

Future research directions will include the refinement and validation of KIM against criteria for typologies, including usefulness in aiding analysis, meaningfulness of category labels, definitions and groupings, completeness, and non-redundancy (Gregor, 2006). The next step is to apply the refined KIM to real-world case studies of innovation in multiple contexts. The model in Figure 2 will serve as a guide to data collection. It is expected that for some innovations the seeds of the innovation will have occurred years before the innovation comes to fruition. For examples, see the NTN/Go8 study of impactful cases in 2012 in Australia (ATN, 2012) and the recent Information Technology \& Innovation Foundation (ITIF) study of major technology advances in the U.S. that resulted from federal research funding (Singer, 2014). The results from these case studies will provide more comprehensive and general guidance for the development of innovation theories and practices.

We conclude with a final observation. We believe that work in innovation research and practice should always define the type of innovation being studied. KIM offers the opportunity to place definitions and categorization of innovations on a solid foundation. 


\section{References}

AACSB. (2008). Impact of research. Final Report of the AACSB International Task Force.

Agrawal, R., Imielinski, T., \& Swami, A. (1993). Mining association rules between sets of items in large databases. Proceedings of the 1993 ACM SIGMOD Conference, Washington, DC, May.

Alavi, M., \& Leidner, D. (2001). Review: Knowledge management and knowledge management systems. Management Information Systems Quarterly, 25(1), 107-136.

Amabile, T. (1983). The social psychology of creativity: A componential conceptualization. Journal of Personality and Social Psychology, 45, 2.

Amabile, T. (2012, April). Componential theory of creativity. Working Paper, Harvard Business School. Accessed 10 March, 2014, from http://www.hbs.edu/faculty/Publication\%20Files/12-096.pdf

Ansoff, I. (1957). Strategies for diversification. Harvard Business Review, 35(5), 113-124.

ATN (Australian Technology Network - Group of 8 Alliance). (2012). Excellence in innovation: Research impacting our nation's future - assessing the benefits. Accessed from http://www.atn.edu.au/Documents/Publications/Reports/2012/ATN-Go8-Report-web.pdf ]

Auh, S., \& Mengue, B. (2005). Balancing exploration and exploitation: The moderating role of competitive intensity. Journal of Business Research, 58, 1652-1661.

Banerjee, P. (2008). Leveraging existing technology: The role of alliances in cross-application. Strategic Management Review, 2(1), 1-22.

Baumol, W. (2002). The free-market innovation machine: Analysing the growth mechanism of capitalism. Princeton: Princeton University Press.

Berndt, D., Hevner, A., \& Studnicki, J. (2003). The CATCH data warehouse: Support for community health care decision making. Decision Support Systems, 35, 367-384.

Block, F., \& Keller, M. R. (2008). Where do innovations come from? Transformations in the U.S. national innovation system, 1970-2006. The Information Technology and Innovation Foundation. Retrieved 5 February, 2013, from http://www.itif.org/files/Where do_innovations_come_from.pdf

Bresnahan, T., \& Trajtenberg, M. (1995). General purpose technologies 'engines of growth'? Journal of Econometrics, 65, 83-108.

Brown, B., \& Anthony, S. (2011). How P\&G tripled its innovation success rate. Harvard Business Review, $89(6), 64-72$.

Brown, S., \& Eisnhardt, K. (1995). Product development: Past research, present findings and future directions. Academy of Management Review, 20, 343-378.

Chaturvedi, A., Dolk, D., \& Drnevish, P. (2011). Design principles for virtual worlds. MIS Quarterly, $35(3), 673-684$.

Chesbrough, H. (2003). Open innovation: The new imperative for creating and profiting from technology. Boston: Harvard Business School Press.

Chesbrough, H., \& Appleyard, M. (2007). Open innovation and strategy. California Management Review, 50(1), 57-76.

Christensen, C. (1997). The innovator's dilemma. New York, NY: Harper Collins.

Clausen, T., Korneliussen, T., \& Madsen, E. (2013). Modes of innovation, resources and their influence on product innovation: Empirical evidence from R\&D active firms in Norway. Technovation, 33, 225233.

Commonwealth of Australia. (2009). Powering ideas: An innovation agenda for the $21^{\text {st }}$ century. Canberra, Australia.

Cowen, T. (2011). The great stagnation. London: Penguin Books. 
Cropley, D., \& Cropley, A. (2010). Functional creativity "products" and the generation of effective novelty, In J. Kaufman \& R. Sternberg (Eds.), The Cambridge handbook of creativity (pp. 301-317). Cambridge University Press.

Danneels, E. (2002). The dynamics of product innovation and firm competencies. Strategic Management Journal, 23, 1095-1121.

Danneels, E. (2004). Disruptive technology reconsidered: A critique and research agenda. Journal of Product Innovation Management, 21(4), 246-258.

David, P. (1990). The dynamo and the computer: An historical perspective on the modern productivity paradox. American Economic Review, 80(2), 355-361.

Davis, F. (1989). Perceived usefulness, perceived ease of use, and user acceptance of information technology. Management Information Systems Quarterly, 13(3), 319-340.

Dolfsma, W., \& Seo, D. (2013). Government policy and technological innovation - A suggested typology. Technovation, 33, 173-179.

Dong, J., Karhade, P., Rai, A., \& Xu, S. (2013). Information technology in innovation activity of the firm: Theory and synthesis. Proceedings of the $21^{\text {st }}$ European Conference on Information Systems, Utrecht, The Netherlands.

Donovan, C., \& Hannay, S. (2011). The 'payback framework' explained. Research Evaluation, 20(3), 181183.

Etzkowitz, H., \& Leydesdorff, L. (2000). The dynamics of innovation: From national systems and "mode 2" to a triple helix of university-industry-government relations. Research Policy, 29, 109-123.

Foray, D. (2004). The economics of knowledge. Cambridge, MA: The MIT Press.

Foss, N. (1996). More critical comments on knowledge-based theories of the firm. Organization Science, $7(5), 519-523$.

Gardner, H. (1993). Creating minds. New York: Basic Books.

Gill, T. G., \& Bhattacherjee, A. (2007). The informing sciences at a crossroads: The role of the client. Informing Science: The International Journal of an Emerging Transdiscipline, 10, 17-39. Retrieved from http://www.inform.nu/Articles/Vol10/ISJv10p017-039Gill317.pdf

Gill, T. G., \& Hevner, A. (2013). A fitness-utility model for design science research. ACM Transactions on Management Information Systems, 4(2), Article 5.

Gould, S., \& Vrba, E. (1982). Exaptation - A missing term in the science of form. Paleobiology, 8(1), 4-15.

Grant, R. (1996). Toward a knowledge-based theory of the firm. Strategic Management Journal 17, 109122.

Gregor, S. (2006). The nature of theory in information systems. MIS Quarterly, 30(3), 611-642.

Gregor, S., \& Hevner, A. (2013). Positioning and presenting design science research for maximum impact. Management Information Systems Quarterly, 37(2), 337-355.

Gregor, S., Imran, A., \& Turner, T. (2013). A 'sweet spot" intervention in a least developed country: Leveraging eGovernment outcomes in Bangladesh. European Journal of Information Systems, 1-17. Advance Online Publication: http://www.palgrave-journals.com/doifinder/10.1057/ejis.2013.14

Gregor, S., \& Jones, D. (2007). The anatomy of a design theory. Journal of the Association of Information Systems, 8(5), 312-335.

Helpman, E. (Ed.). (1998). General purpose technologies and economic growth. Cambridge, MA: MIT Press.

Hevner, A., March, S. Park, J., \& Ram, S. (2004) Design science research in information systems. MIS Quarterly, 28(1), 75-105. 
Horenstein, M. (2002). Design concepts for engineers (2nd ed.). Upper Saddle River, NJ: Prentice-Hall. Inmon, W. (1992). Building the data warehouse. New York: Wiley and Sons Publishers.

Innovaro. (2008). Innovation briefings - Innovation leaders 2008. Retrieved from http://fp05527.web.dircon.net/Innovation\%20Leaders\%202008.pdf

Jeppesen, L., \& Lakhani, K. (2010). Marginality and problem-solving effectiveness in broadcast search. Organization Science, 21(5), 1016-1033.

Kelly, T. (2002). The art of innovation: Lessons in creativity from IDEO. New York: Harper Collins.

Leonard, D. (1998). Wellsprings of knowledge: Building and sustaining the sources of innovation. Boston: Harvard Business School Press.

Leonard-Barton, D. (1992). Core capabilities and core rigidities: A paradox in managing new product development. Strategic Management Journal, 13, 111-125.

Lerner, J. (2012). The architecture of innovation. Oxford, UK: Oxford University Press.

Levinthal, D., \& March, J. (1993). The myopia of learning. Strategic Management Journal, 14, 95-112.

Linden, A., \& Fenn, J. (2003, May 30). Understanding Gartner's hype cycles, Strategic Analysis Report. Gartner, Inc. Retrieved 10 March, 2014 from https://www.gartner.com/doc/396330

Lipsey, R., Carlaw, K., \& Bekar, C. (2005). Economic transformations: General purpose technologies and long term economic growth. Oxford: Oxford University Press.

March, J. (1991). Exploration and exploitation in organizational learning. Organization Science, 2(1), 71 87.

Mascitelli, R. (2000). From experience: Harnessing tacit knowledge to achieve breakthrough innovation. Journal of Product Innovation Management, 17(3), 179-193.

McLaren, T., Head, M., Yuan, Y., \& Chan, Y. (2011). A multilevel model for measuring fit between a firm's competitive strategies and information systems capabilities. Management Information Systems Quarterly, 35(4), 909-929.

Mokyr, J. (2002). The gifts of Athena: Historical origins of the knowledge economy. Princeton, NJ: Princeton University Press.

Nonaka, I. (1991). The knowledge-creating company. Harvard Business Review, Nov-Dec., 96-104.

Nonaka, I., Toyama, R., \& Nagata, A. (2008). A firm as a knowledge-creating entity: A new perspective on the theory of the firm. Industrial and Corporate Change, 9(1), 1-20.

Nunamaker, J., Dennis, A., Valacich, J., \& Vogel, D. (1991). Information technology to support negotiating groups: Generating options for mutual gain. Management Science, 37(10), 1325-1346.

Nunamaker, J., Dennis, A., Valacich, J., Vogel, D., \& George, J. (1991). Electronic meeting systems to support group work. Communications of the ACM, 34(7), 40-61.

Nunamaker, J., Derrick, D., Elkins, A., Burgoon, J., \& Patton, M. (2011). Embodied conversational agentbased kiosk for automated interviewing, Journal of Management Information Systems, 28(1), 17-48.

Parnas, D. (2011). Software engineering - missing in action: A personal perspective. Computer , 44(10), 54-58.

Peffers, K., Tuunanen, T., Rothenberger, M., \& Chatterjee, S. (2008). A design science research methodology for information systems research. Journal of MIS, 24(3), 45-77.

Ray, S. (2008) Innovative IT: Enabling pharmaceutical research \& development. Pharma Focus Asia, 9 , 79-82.

Rockart, J., \& De Long, D. (1988). Executive support systems: The emergence of top management computer use. Homewood, IL: Business One Irwin. 
Rogers, E. (2003). Diffusion of innovations (5th ed.). New York: Free Press.

Rothwell, R., \& Gardiner, P. (1983). Tough customers, good design. Design Studies, 4(3), 161-169.

Rothwell, R., \& Gardiner, P. (1985). Invention, innovation, re-innovation and the role of the user. Technovation, 3,168

Savransky, S. (2000). Engineering of creativity. Boca Raton, FL: CRC Press.

Schumpeter, J. (1934). The theory of economic development. Cambridge, MA: Harvard University Press

Schumpeter, J. (1942). Capitalism, socialism, and democracy. New York, NY: Harper Press.

Scott-Morton, M. (1967). Computer-driven visual display devices - Their impact on the management decision-making process. Unpublished $\mathrm{PhD}$ thesis, Harvard Business School.

Simon, H. (1996). The sciences of the artificial (3rd ed). Cambridge, MA: MIT Press.

Singer, P. (2014). Federally supported innovations: 22 examples of major technology advances that stem from federal research support. The Information Technology \& Innovation Foundation Report.

Solow, R. (1987, July 12). We'd better watch out. New York Times Book Review, p. 36.

Spender, J. (1996) Making knowledge the basis of a dynamic theory of the firm. Strategic Management Journal, 17, 45-62.

Sternberg, R., Kaufman, J., \& Pretz, J. (2002).The creativity conundrum: A propulsion model of kinds of creative contributions. New York: Psychology Press.

Stokes, D. (1997). Pasteur's quadrant: Basic science and technological innovation. Washington, DC: Brookings Institute Press.

Tidd, J., \& Bessant, J. (2009). Managing innovation integrating technological, market and organizational change (4th ed.). Chichester, UK: John Wiley \& Sons.

Van de Ven, A., \& Poole, M. (1990). Methods for studying innovation development in the Minnesota innovation research program. Organizational Science, 1(3), 313-335.

Van de Ven, A., Polley, D., Garud, R., \& Venkataraman, S. (2008). The innovation journey. New York, NY: Oxford University Press.

von Hippel, E. (1986). Lead users: A source of novel product concepts. Management Science, 32(7), 791805.

von Hippel, E., \& von Krogh, G. (2013). Identifying viable "need-solution pairs": Problem solving without problem formulation.DSpace@MIT. Massachusetts Institute of Technology. Engineering Systems Division. Retrieved 10 March, 2014 from http://hdl.handle.net/1721.1/82610

Zobel, J. (2005). Writing for computer science (2nd ed.). London: Springer-Verlag. 


\section{Appendix A: Comparison of Typologies}

\section{Table A1 Comparison of KIM with other Typologies}

\begin{tabular}{|c|c|c|c|}
\hline $\begin{array}{l}\text { Knowledge Innovation } \\
\text { Matrix (KIM) }\end{array}$ & $\begin{array}{c}\text { Knowledge- } \\
\text { Contribution Frame- } \\
\text { work } \\
\text { Gregor and Hevner } \\
\text { (2013) }\end{array}$ & $\begin{array}{c}\text { Product-Market Ma- } \\
\text { trix }^{1} \\
\text { Ansoff }(1957)\end{array}$ & $\begin{array}{c}\text { Competence-Product } \\
\text { Typology } \\
\text { Danneels }(2002)\end{array}$ \\
\hline $\begin{array}{l}\text { Invention/Radical in- } \\
\text { novation: New prob- } \\
\text { lems (applications) } \\
\text { and new solutions } \\
\text { (knowledge) }\end{array}$ & $\begin{array}{l}\text { Invention: } \\
\text { Clear departure from } \\
\text { accepted ways of } \\
\text { thinking }\end{array}$ & $\begin{array}{l}\text { Diversification: A } \\
\text { simultaneous depar- } \\
\text { ture from the present } \\
\text { product line and the } \\
\text { present market struc- } \\
\text { ture. }\end{array}$ & $\begin{array}{l}\text { Pure exploration: New } \\
\text { product is a tool to } \\
\text { build new competen- } \\
\text { cies for both technolo- } \\
\text { gies and customers. }\end{array}$ \\
\hline $\begin{array}{l}\text { Improvement: New } \\
\text { solutions for known } \\
\text { problems }\end{array}$ & $\begin{array}{l}\text { Improvement: Better } \\
\text { solutions for a known } \\
\text { application context. }\end{array}$ & $\begin{array}{l}\text { Product development: } \\
\text { New and different } \\
\text { products to improve } \\
\text { company mission. }\end{array}$ & $\begin{array}{l}\text { Leveraging customer } \\
\text { competence: Building } \\
\text { additional technology } \\
\text { competencies for ex- } \\
\text { isting needs. }\end{array}$ \\
\hline $\begin{array}{l}\text { Exaptation: Extend } \\
\text { known solutions to } \\
\text { new problems (i.e. } \\
\text { other fields) }\end{array}$ & $\begin{array}{l}\text { Exaptation: Ideas and } \\
\text { artifacts from one } \\
\text { field used to solve } \\
\text { problems in another } \\
\text { field. }\end{array}$ & $\begin{array}{l}\text { Market development: } \\
\text { The company at- } \\
\text { tempts to adapt its } \\
\text { present product line } \\
\text { to new missions. }\end{array}$ & $\begin{array}{l}\text { Leveraging technology } \\
\text { competence: Appeal to } \\
\text { new customers } \\
\text { through extending } \\
\text { products based on } \\
\text { known technology. }\end{array}$ \\
\hline $\begin{array}{l}\text { Adoption/ } \\
\text { Exploitation: Apply } \\
\text { known solutions to } \\
\text { known problems }\end{array}$ & $\begin{array}{l}\text { Routine design: Ex- } \\
\text { isting knowledge is } \\
\text { well understood and } \\
\text { applied in familiar } \\
\text { knowledge areas in a } \\
\text { routine way. }\end{array}$ & $\begin{array}{l}\text { Market penetration: } \\
\text { Increase company } \\
\text { sales without depart- } \\
\text { ing from the initial } \\
\text { product-market strat- } \\
\text { egies. }\end{array}$ & $\begin{array}{l}\text { Pure exploitation: } \\
\text { Firm uses both exist- } \\
\text { ing technological and } \\
\text { customer competen- } \\
\text { cies. }\end{array}$ \\
\hline
\end{tabular}

Notes on broad equivalence of terms:

${ }^{1}$ Knowledge approximates product line; application approximates markets

${ }^{2}$ Knowledge approximates technology competence; application approximates customer competence 


\section{Appendix B: The Overarching Dimensions of Innovation}

The literature that was reviewed shows that knowledge and its application in specific real-world problem domains are central concepts in understanding innovation. Tables B1 and B2 provide a summary of innovation concepts organized around these two central concepts. The Tables also show the definitions of the two key dimensions that we use in the development of KIM. They provide evidence to support the view that many conceptualizations of innovation rely on these dimensions, albeit with some differences in terminology. We conclude that the two overarching dimensions, knowledge maturity and application domain maturity, can be used to give a highlevel perspective that encompasses many of the varying definitions and viewpoints on innovation.

Our working definition of innovation follows Rogers (2003, p. 12): “An innovation is an idea, practice or object that is perceived as new by an individual or other unit of adoption. It matters little, so far as human behaviour is concerned, whether or not an idea is 'objectively' new as measured by the lapse of time since its first use or discovery".

\section{Table B1: The Knowledge Dimension and Related Concepts in Innovation Studies}

\begin{tabular}{|c|c|}
\hline $\begin{array}{l}\text { Knowledge Maturit } \\
\text { The knowledge matu } \\
\text { concerning innovatic } \\
\text { and human ideas, tad } \\
\text { in academic articles } \\
\text { tly in the innovation }\end{array}$ & $\begin{array}{l}\text { y dimension in relation to innovation refers to a range of useful knowledge } \\
\text { oroducts, processes and solutions in general, that includes creative thought } \\
\text { human knowledge, organizational knowledge, and knowledge represented } \\
\text { knowledge repositories. The knowledge may also be represented implic- } \\
\text { elf e.g., in its appearance and form and functions). }\end{array}$ \\
\hline Related concepts & $\begin{array}{l}\text { Definitions } \\
\text { (with emphasis added) }\end{array}$ \\
\hline idea & $\begin{array}{l}\text { "An innovation is an idea, practice or object that is perceived as new by } \\
\text { an individual or other unit of adoption." (Rogers, 2003, p. 12) }\end{array}$ \\
\hline & "invention is the creation of a new idea" (Van de Ven et al., 2008, p. 9) \\
\hline & $\begin{array}{l}\text { "innovation is the process of developing and implementing a new idea" } \\
\text { and is more encompassing than invention (Van de Ven et al., 2008, p. 9) }\end{array}$ \\
\hline knowledge & $\begin{array}{l}\text { "Innovation is about knowledge - creating new possibilities through } \\
\text { combining different knowledge sets" (Tidd \& Bessant, 2009, p. 37) }\end{array}$ \\
\hline exploration & $\begin{array}{l}\text { "exploration - the pursuit of new knowledge" (Levinthal \& March, } \\
1993, \text { p. } 105 \text { ) }\end{array}$ \\
\hline exploitation & $\begin{array}{l}\text { "exploitation - the use and development of things already known" } \\
\text { (Levinthal \& March, 1993, p. 105) }\end{array}$ \\
\hline $\begin{array}{l}\text { incremental innova- } \\
\text { tion }\end{array}$ & $\begin{array}{l}\text { innovation includes even small changes in technological know-how - } \\
\text { an improvement or incremental innovation (Rothwell \& Gardiner, 1985) }\end{array}$ \\
\hline platform innovation & $\begin{array}{l}\text { continuous incremental innovation can be achieved through use of plat- } \\
\text { forms - a platform or robust design (knowledge) that can be modified } \\
\text { to give a family of products (Rothwell \& Gardiner, 1983) }\end{array}$ \\
\hline radical innovation & $\begin{array}{l}\text { a major advance in the technological state-of-the art (Rothwell \& Gar- } \\
\text { diner, 1985) }\end{array}$ \\
\hline $\begin{array}{l}\text { breakthrough innova- } \\
\text { tion }\end{array}$ & $\begin{array}{l}\text { "Whereas evolutionary product improvements often follow predictable } \\
\text { trajectories, breakthrough innovations involve unexpected leaps of crea- } \\
\text { tivity and insight." (Mascitelli, 2000, p. 179) }\end{array}$ \\
\hline expertise & $\begin{array}{l}\text { The } 10 \text { year rule: "An apprenticeship of at least } 10 \text { years is necessary for } \\
\text { acquiring the foundation for creativity" (Gardner, 1993) }\end{array}$ \\
\hline
\end{tabular}




\begin{tabular}{|l|l|}
\hline $\begin{array}{l}\text { organizational learn- } \\
\text { ing }\end{array}$ & $\begin{array}{l}\text { "Organizations store knowledge in their procedures, norms rules, and } \\
\text { forms. They accumulate suck knowledge overtime, learning from their } \\
\text { members." (March, 1991). }\end{array}$ \\
\hline $\begin{array}{l}\text { firm resources/ com- } \\
\text { petencies }\end{array}$ & $\begin{array}{l}\text { employee knowledge and skills, technical systems, administrative sys- } \\
\text { tems, values and norms (Leonard-Barton, 1992) }\end{array}$ \\
\hline
\end{tabular}

\section{Table B2: The Application Domain Dimension and Related Concepts} in Innovation Studies

\begin{tabular}{|c|c|}
\hline \multicolumn{2}{|c|}{$\begin{array}{l}\text { Application Domain Maturity: } \\
\text { The application domain maturity dimension in relation to innovation refers to the opportunity or } \\
\text { problem, broadly conceived, to which the innovation is applied. Its range includes initial recogni- } \\
\text { tion of opportunities in a target domain (rather than defined problems), known problems and their } \\
\text { existing solutions, niche target domain needs and mainstream target domain needs. The target } \\
\text { domain may relate to customers or markets, or other consumers as in health, or some useful } \\
\text { knowledge domain, such as database techniques. Greater maturity means greater understanding of } \\
\text { the opportunities and needs across possible target domains. }\end{array}$} \\
\hline Related concepts & $\begin{array}{l}\text { Definitions } \\
\text { (with emphasis added) }\end{array}$ \\
\hline opportunities & $\begin{array}{l}\text { We need to consider the outputs of the innovation process. "In what } \\
\text { ways can we innovate - what kinds of opportunities exist to create } \\
\text { something different and capture value...?" (Tidd \& Bessant, 2009, } \\
\text { p. 20) }\end{array}$ \\
\hline tasks/problems & $\begin{array}{l}\text { cal, useful creativity (innovation) involves "devices or systems } \\
\text { rform tasks or solve problems" (Horenstein, 2002, p. 2) }\end{array}$ \\
\hline field transfer & $\begin{array}{l}\text { Tany novel ideas are based on what already exis } \\
\text { owledge is transferred to a field quite differe } \\
\text { ich it is already known" (Cropley \& Cropley, } 201\end{array}$ \\
\hline market & $\begin{array}{l}\text { "Equally important [in innovation] is the ability to spot where and how } \\
\text { new markets can be created and grown" (Tidd \& Bessant, 2009, p. 21) }\end{array}$ \\
\hline $\begin{array}{l}\text { disruptive technology/ } \\
\text { innovation }\end{array}$ & $\begin{array}{l}\text { "The products based on the disruptive technology initially only satisfy a } \\
\text { niche market segment... Overtime, the performance supplied by the } \\
\text { disruptive technology improves to the point where it can satisfy the re- } \\
\text { quirements of the mainstream market." (Danneels, 2004, p. 247) }\end{array}$ \\
\hline
\end{tabular}

\section{Biographies}

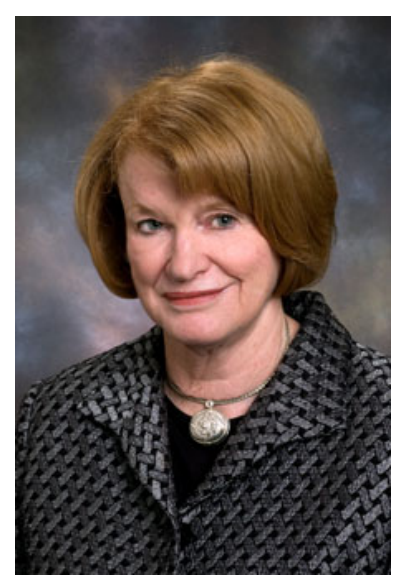

Shirley Gregor is Professor of Information Systems at the Australian National University, Canberra, where she is a Director of the National Centre for Information Systems Research. Professor Gregor's research interests include the adoption and strategic use of information and communications technologies, intelligent systems, human-computer interaction and the philosophy of technology. Dr Gregor has published in journals such as MIS Quarterly, Journal of the Association of Information Systems, European Journal of Information Systems and Information Technology \& People. Professor Gregor was made an Officer of the Order of Australia in June 2005 for services as an educator and researcher in the field of information systems and for work in ecommerce in the agribusiness sector. She is a Fellow of the Australian Computer Society and a Fellow of the Association for Information Systems. 


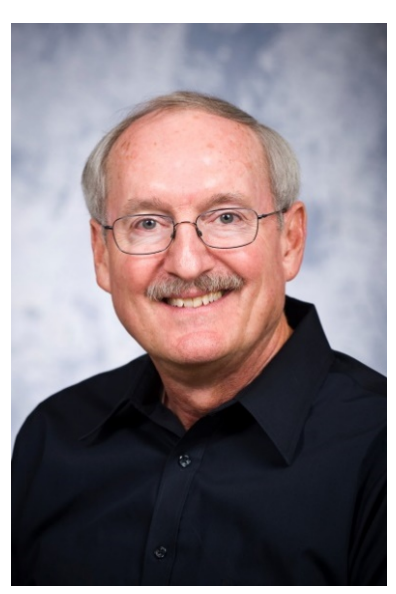

Alan R. Hevner is an Eminent Scholar and Professor in the Information Systems and Decision Sciences Department in the College of Business at the University of South Florida. He holds the Citigroup/Hidden River Chair of Distributed Technology. Dr. Hevner's areas of research interest include design science research, information systems development, software engineering, distributed database systems, healthcare systems, and service-oriented computing. He has published over 200 research papers on these topics and has consulted for a number of Fortune 500 companies. Dr. Hevner received a Ph.D. in Computer Science from Purdue University. He has held faculty positions at the University of Maryland and the University of Minnesota. Dr. Hevner is a Fellow of the American Association for the Advancement of Science (AAAS) and is a member of ACM, IEEE, AIS, and INFORMS. From 2006 to 2009, he served as a program manager at the U.S. National Science Foundation (NSF) in the Computer and Information Science and Engineering (CISE) Directorate. 